\title{
HEARING THE HIDDEN AGENDA: THE ETHNOGRAPHIC INVESTIGATION OF PROCEDURE
}

\author{
John M. Conley* and William M. O'Barr $†$
}

\section{INTRODUCTION}

Everyone seems to be mad at the American legal system. Among lawyers, judges, legal scholars, and self-proclaimed public interest advocates of various ideological persuasions, it is hard to find anyone who will dispute the proposition that America's system of civil justice is in need of major reform.

The debate over the sources of this dissatisfaction tends to follow certain well-worn paths. ${ }^{1}$ Delay and expense often head the list of suspects. ${ }^{2}$ Those concerned about delay often argue that Americans file too many lawsuits, ${ }^{3}$ dragging the courts into areas where they have no business. ${ }^{4}$ Others focus on the related problem of cost. Lawyers' fees are too high to start with, it is argued, and the problem is compounded by inevitable delays. ${ }^{5}$ Many critics also identify a decline in the competence and ethical standards of lawyers as a source of dissatisfaction with the law. ${ }^{6}$

Anyone who has had experience with the legal system will recognize substantial elements of truth in all of these assertions. People do file frivolous suits, courts sometimes do go beyond their competence, litigation is too expensive for most people, and some lawyers do perform poorly. There can

Copyright (C) 1988 by Law and Contemporary Problems

* Professor, School of Law, University of North Carolina, Chapel Hill, North Carolina.

+ Professor, Departments of Cultural Anthropology and Sociology, Duke University. Durham, North Carolina.

The research reported in this paper is the result of a joint project. The authors alternate priority of authorship in their publications. The research was supported by grants (SES 85-21528 and 8521547) from the Law and Social Science Program of the National Science Foundation. The authors acknowledge with appreciation the assistance of the officials of the small claims courts in the North Carolina, Colorado, and Pennsylvania cities where this research was conducted, and of their research assistants, Mark Bielawski, Mark Childress, Mitchell Ducey, Rebecca Schaller, and Amy Thomas.

1. For a review of this conventional critique and a thoughtful rejoinder, see Galanter, Reading

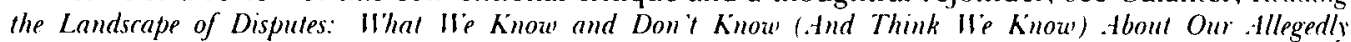
Comentious and Litigious Society, 31 UCLA L. REv. 4 (1983).

2. Sep, e.g., Burger, Isn't There a Better IIay? 68 A.B.A. J. 274, 274 (1982).

3. Sep Galanter, supra note 1, at 7-8, 62-63.

4. See id. at 10-11: Burger, supra note 2, at 275.

5. Sep Trubek, Sarat, Felstiner, Kritzer \& Grossman, The Costs of Ordinary Litigation. 31 UCLA L. REv. 72, 74 n.l (1983); Rosenberg, Civil Justice Research and Civil Justice Reform, 15 Law \& Soc'y Rev. 473, $481-83(1980-81)$.

6. See Galanter, supra note 1, at 11; Burger, The Role of the Lau School in the Teaching of Legal Ethics and Professional Responsibility. 29 Cl.ev. ST. L. Rev. 377. 379-83 (1980). 
be little question that all of these factors contribute to public dissatisfaction with and disrespect for the legal system, and all deserve attention when considering legal reform.

After three years of studying lay people in the informal courts ${ }^{7}$ of Colorado, North Carolina, and Pennsylvania, however, we believe that debate on this level may mask even deeper problems. Implicit in conventional critiques is the assumption that most litigants come to the legal system to pursue discrete, usually economic objectives. Dissatisfaction results when expense, delay, professional malfeasance, or some comparable factor complicates the pursuit. In other words, it is assumed that litigants understand the purpose of the law and are frustrated by flaws in its delivery. ${ }^{8}$ Historically, reform movements have focused on problems of delivery and have been evaluated in terms of their ability to solve those problems."

This article presents extracts from a large corpus of ethnographic data that cast doubt on these assumptions. Using anthropological and linguistic research methods, we have investigated litigants' "hidden agendas" 10 - the unappreciated factors that cause people to resort to the legal system and the undisclosed objectives that they pursue within the system. Every trial lawyer has dealt with clients driven by hidden agendas: the plaintiff who rejects an economically reasonable settlement out of pride or anger, or the corporate official who capitulates too quickly out of fear of disclosure of an office romance. " To our knowledge, however, there has been no scholarly effort to study the significance of litigants' hidden agendas, perhaps because of their inaccessibility to conventional research techniques. ${ }^{12}$ This article attempts to demonstrate that although hidden agendas may indeed be inaccessible to

7. As we use the term, informal courts are small claims and similar courts which use relaxed rules of procedure and evidence in adjudicating cases with limited amounts in controversy. The most significant feature of all of these courts is that they encourage lay people to litigate their cases without lawyers. For a more complete description of the particular courts we studied, see Conley \& O'Barr, Fundamenlals of Jurisprudence: th Elhnography of Judicial Decision . Making in Informal Courts, 66 N.C.L. Rrv. $467,476.77$ (1988).

8. See Irubck. Access Ilithout Justice? On Reading and I'sing the Veuer Law and Society Literature, I.AW \& Contrim. Probs., Autumn 1988, at 111 .

9. A review of the history of legal reform is well beyond the scope of this article. For illustrations of the point made in the iext, see Walker, Perfecting Federal Civil Rules: A Proposal for Restricted Field Experiments, Law \& Contemp. Probs., Summer 1988, at 67 (discussing the evaluation of the Federal Rules of Civil Procedure); Metzloff, Empinical Perspectives on .Medical Malpractice Litigation, I AW \& Contemp. Probs., Autumn 1988, at 199 (study of medical malpractice litigation).

10. To our knowledge, the term first appeared in the sociolegal literature in Vidmar, The Small Claims Count: A Reconreptualization of Dispules and an Empirical Inzestigation, 18 LAw \& Soc'Y REv. 515. 515 (1984).

11. Hidden agendas are visible even from the pinnacle of the American legal system. Sep Burger, supra note 2, at 275 ("Americans are increasingly turning to the courts for relief from a range of personal distresses and anxieties.").

12. There is, of course, abundant experimental evidence from the procedural justice tradition that litigants concern themselves with issues other than the outcome of their cases. Sep infra note 20. The comment in the text is directed to the lack of study of hidden agendas as they operate in actual litigation. Vidmar, supra note 10 , has recognized the importance of hidden agendas in his research on small claims courts. In their ongoing study of mediation, McEwen and Maiman have also recognized some of the specific extralegal factors that contribute materially to litigant satisfaction. Sep McFwen \& Maiman, Coerrion and Consent: A Tale of Two Court Reforms, 10 Law \& Poi.' 3 (1988). 
those relying on records collected and kept by the courts or on social science data collected with a view toward quantification, they are discoverable if one pays close attention to what litigants say in and out of court.

Extensive linguistic evidence supports the existence and importance of hidden agendas. These agendas have both substantive and procedural components: Many litigants come to court in pursuit of objectives beyond the limited competence of the law, while others seek rewards from their participation in the process that bear little relation to the favorable judgment that is the presumed goal of every litigant. We conclude that the discontinuity between litigant agendas and the operating assumptions of the system may be a fundamental source of public dissatisfaction with the law. Accordingly, we argue, the effort to understand litigants' hidden agendas is an essential component of any thoughtful attempt to evaluate existing procedures or design new ones.

\section{The Method: The Ethnography of Discourse}

The research reported here is part of a three-year study of lay people in the legal process. ${ }^{13}$ The focus of the project has been on the general issues of lay people's understandings of the law and reactions to the legal process. Specific questions such as how lay people decide when they have a legal problem, how they develop legal theories, and how they decide the things that constitute adequate proof and appropriate evidence have been studied. ${ }^{14}$ The research has also yielded abundant data on the topic discussed here-litigant goals and motivations.

We have studied informal court litigants in three states: Colorado, North Carolina, and Pennsylvania. ${ }^{15}$ We collected data at three stages in the litigation process. Plaintiffs were interviewed as they came to court to file their cases ${ }^{16}$ and were observed and tape recorded during their trials. In addition, plaintiffs and defendants were interviewed after trial. ${ }^{17}$ An openended interview technique was used to encourage litigants to talk about their cases and their views of the law and the legal process. The litigants were permitted to guide the interviews, and the researchers introduced topics of

13. The findings of this research project to date have been reported in several articles. These include: Conley \& O’Barr, supra note 7: O’Barr \& Conley, Litigamt Satisfaction l'ersus Legal Adequary in Small Claims Court Danatives, 19 Law \& Soc'y Rev. 661 (1985): Conley \& O'Barr, Rules Iersus Relationships in Small Claims Disputes, in Confl.ict TAt.k (A. Grimshaw ed., forthcoming 1989); O'Barr \& Conley, Lay Expertations of the Civil Justice System, 22 I Aw \& Soc'v REv. 137 (1988).

14. Supra note 13.

15. For a more complete discussion of our reasons for selecting these jurisdictions, sec Conley \& O'Barr, supra note 7, at 476-77.

16. Our intention was to find and interview defendants before trial as well, but most proved difficult to locate and unwilling to be interviewed. A few suspected that we were agents of the plaintiff or the court, and many others were simply so angry that they had been sucd that they did not want to talk about it.

17. The data collection was carried out under confidentiality agreements approved by the various courts. 
concern to the research program only when the litigants themselves failed to do so. In the course of the investigation, more than 100 cases were studied in this manner.

Our analytic method, called the ethnography of discourse, relies on the detailed scrutiny of litigant speech. Its basic premise is that the careful, qualitative study of unrehearsed speech can provide important clues to the goals, strategies, and thought processes of the speaker. ${ }^{18}$ At the conclusion of the data collection phase of the project, we prepared transcripts of each interview and trial. We studied the cases in analytic sessions in which we and three or four other researchers trained in law, social science, or both focused our native-speaker intuition and varied professional perspectives on the data. In a typical two-hour session, we analyzed a single case or interview of average length (five to ten pages of text), or a segment of a longer one. With the transcript in front of us, we listened to the recording several times and then spent about twenty minutes writing notes about those features that were of interest to us. We then engaged in a round-table discussion of our observations.

The issues in this article were not identified in advance, but emerged as significant questions because they attracted the attention of the analysts repeatedly. Because the speech of the litigants was the only data, these issues were drawn to the reseachers' attention by the litigants themselves. Although the method used, which has substantial precedent in social science research, ${ }^{10}$ does not yield simple, categorical, or readily quantifiable results, its use avoids the a priori judgments that are inherent in survey or directed interview techniques and is thus particularly well suited for identifying the hidden concerns and strategies of litigants.

The remainder of this article presents two cases that illustrate, respectively, the nature of procedural and substantive hidden agendas. Only two cases are presented because the method requires the presentation and fine-grained analysis of lengthy texts. However, these cases and the conclusions drawn from them are representative of many other cases investigated.

\section{III}

\section{Procedural Goals: Law as Therapy}

The first case illustrates the simple but significant fact that some litigants come to the legal process with a hidden agenda that has important procedural components. The recognition that litigants are concerned with procedure is not new. Indeed, experimental research in the procedural justice tradition has shown convincingly that litigants sometimes value procedural fairness

18. "[L/anguage patterns are unconscious and provide access to unconscious cultural patterning otherwise inaccessible to researchers." Sherzer, A Disowrse-Centered Approach to Language and Cultwe, 89 Am. Anturopologist 295, 295 (1987) (discussing the work of three of the founders of modern linguistics, Boas, Sapir, and Whorf)

19. Sep, p.g., J. Atkinson \& P. Drew, Order in Colirt 1-33 (1979). 
over a successful outcome in evaluating legal processes. ${ }^{20}$ Missing from the literature is a means of specifically identifying litigants' concerns about procedure as they develop in actual litigation. The ethnography of discourse is particularly well suited to this task because the litigants identify the specific issues of concern to them. The evolution and treatment of these issues can be followed as the litigants think and speak about them.

The plaintiff in the first case, Sarah Freeman, 21 is a young graphic artist. She contracted with the defendant, a manufacturer's representative doing business as a corporation, to design a logo, stationery, and business cards. When she tried to deliver the work and collect her fee, the defendant refused to talk to her. She sued the corporation to collect the fee.

Freeman arrived in court on the trial date with the contract, her record of correspondence with the defendant, and her portfolio. The defendant failed to appear. The judge raised an initial question about whether Freeman intended to sue the corporation (the defendant she had served with process) or its proprietor. Freeman asked the judge's opinion and he told her that he was not allowed to give legal advice, and that she should consult a lawyer. She was excused from the courtroom to do so. When she returned, acting on the advice of her lawyer, she asked for a default judgment against the corporate defendant. The judge questioned her briefly in order to establish the elements of the contract claim and the basis for her damages and then entered judgment for the amount she claimed. The entire proceeding took about two minutes.

We later interviewed the judge who had heard the Freeman case. We asked him about default cases in general, and in particular about this case, which he remembered. In Text $1 \mathrm{~A}$ the judge explains his policy for handling defaults and makes specific reference to Sarah Freeman.

Text lA

JUDGE: Yeah, O.K. But what they don't recognize is this-they ve gotta be prepared, as if the person is going to be there and defend against the case. But what they don't recognize is the fact that if the person isn't there, that all I've got to do is do what we call a prima facie case. We don't have to get involved with all these details. She got her judgment.

INTERVIEWER: Oh, she gol everything she wanted?

JUDGE:

That's what I said-she got everything she wanted. And what they don't recognize is why should we take the time to go into all these details just to give her her day in court when

20. Research in the procedural justice tradition began with the publication of J. THIBaut \& L. Walker, Procedural. Justick: A Psicholocical. Analisis (1975). In the last few years, procedural justice researchers have begun to isolate sonce of the psychological factors that influence disputants' procedural preferences. See, e.g., Brent \& Goldberg, Crienance . Mediation in the Coal Industry: A Field Experimenl, 37 Indus. \& LAB. RE.l. REv. 49 (1983) (disputants valuc control of process because they view it as a means of controlling outcome); Tyler, Rasinski \& McGraw, The Influence of Perceined Injustice on the Endorsement of Political Leaders, $15 \mathrm{~J}$. App. Soc. Psicnolocy 700 (1985) (process control valued as guarantec of opportunity for self-expression). For a recent and comprehensive review of the field, sec E. Lind \& T. Tyifr, Thy Sociat. Psychology of Procediral Jusmice (1988).

21. In order to protect the privacy of the parties whose cases we report in this article, original names and other identifying features have been changed. 
she got what she wanted. All she came in for was the judgment.

From the perspective of judicial administration, it is difficult to imagine a more thoroughly reasonable policy. Out of concern for the rights of the absent defendant, the judge insists on the presentation of a prima facie case. However, in order to save the time of the plaintiff and those waiting in the courtroom for their cases to be heard, the judge hears nothing more than a skeletal prima facie case before awarding the judgment."2 He thus balances the interests of justice and convenience in a seemingly appropriate way.

We interviewed Freeman shortly after her case was heard and found her to be one of the most dissatisfied litigants we have encountered in three years of research. In Text $1 \mathrm{~B}$, she responds to our request to discuss the procedure the judge followed.

\section{TEXT $1 \mathrm{~B}$}

FREEMAN:

I feel like I am furious I didn't get to tell that [my story]. I spent, you know, a good part of my night last night preparing that, to have the judge not give a damn, basically is how I felt. I felt he was very short. I felt that he was not, um, let me put it, a little less than professional in the way that he was dealing with that court today. Personally, um ...

INTERVIEWER: Could you say what you mean by "a little less than professional"? What reason ...

FREEMAN: Yeah, he was giving me information. He was jumbling things for me so that I didn't understand it. And he was expecting me to understand what was going on there like I am a lawyer. I am not a lawyer. He failed to listen to what $I$ had to say.

INTERVIEWER: By listening to what you had to say, do you mean the context and the, uh ...

FREEMAN:

My presentation. And there's a reason why I spent that kind of time putting it together.

INTERVIEWER: Like what would you have said in your presentation? What was it all about?

FREEMAN:

My presentation just delineated how things developed, that he owed me the money, um, the meetings that took place, the understandings of how much money he owed me, um, some other information about the company as well as the payments he made for payments. Some other things-and I explained it in the presentation.

The most striking aspect of Text $1 \mathrm{~B}$ is the clash of perspectives between judge and litigant. The attitude that the judge sees as efficient, Freeman sees as "short." What the judge seems to view as a fair balancing of interests, Freeman views as "less than professional." Most significantly, whereas the judge believed that "all she came in for was the judgment," Freeman never even mentioned the judgment as mitigating the procedural affront she had received.

The conflict between Freeman and the judge suggests several things about the evaluation of procedure. On a general level, it confirms that procedure is sometimes more important to lay litigants than outcome, a point that

22. Later in the interview, the judge noted that he calls the complete list of cases at the start of each court session and disposes of all the defaults before starting the contested cases. 
procedural justice research has clearly established in laboratory contexts. ${ }^{23}$ The case also illustrates that even sophisticated litigants often misunderstand the most basic legal concepts. ${ }^{24}$ Thus, Freeman felt that the judge was treating her like a lawyer when he asked her to declare her intention to sue an individual or a corporate defendant.

More specifically, the case demonstrates that litigants' hidden agendas sometimes have significant procedural components. In identifying their objectives in coming to court, litigants may focus not only on ends they hope to achieve, but on procedural opportunities that are of importance to them. Freeman echoed a procedural concern we have heard from many litigants: the need to tell one's story. In a variety of contexts, litigants have recounted that the opportunity to tell their whole story is sometimes more important than the result. ${ }^{25}$ Some losers have reported that the chance to tell their story to the judge made the whole effort worthwhile, whereas some winners, such as Freeman, have gone away dissatisfied because their story went untold.

The telling of the story seems to be important for two reasons. First, many people see the litigation process as a form of therapy. As in other kinds of therapy, the central, cathartic element is the chance to relate one's troubles to an authoritative yet sympathetic listener. ${ }^{26}$ A second, related issue that emerges from our data is the desire expressed by many litigants for "official" validation of the seriousness of their problems. As Freeman put it, it was devastating-irrespective of the outcome-"to have the judge not give a damn." A number of other, unsuccessful litigants have commented on how important it was for the judge to show appreciation for the gravity of their situation, even if no legal help was forthcoming. For such litigants, the dominant emotion seems to be relief at learning that someone in a position of authority understands why they are upset.

Lawyers and judges with whom we have discussed the issue of procedural hidden agendas have sometimes rejected our findings out of hand, observing that the legal system has neither the resources nor the expertise to address litigants' psychological needs. However, the demands that litigants such as Freeman make on the system are often minimal. For example, she acknowledged in the interview that she understood that there was no legal reason for the judge to hear her story. She would have been satisfied if the judge had only "said to me the case is decided, period, no matter what you have to say from here on out. I'm sorry that you wasted your time, you wasted your time on your presentation." All she sought was "some sort of understanding." In her words, "[t]hat would have taken care of it." By paying attention to what litigants say rather than acting on assumptions about

23. See supra note 20.

24. Sep O'Barr \& Conley, Lay Expectations of the Civil Justice System, 22 Law \& Soc'Y REv. 137 (1988).

25. Cf. Yngresson \& Hennessey. Small Claims. Complex Dispules: t Reriew of the Simall Claims Literalue, 9 L Aw \& Soc'y Rev. 219, 260 (1975) (opportunity for self-expression contributes to litigants' willingness to compromise).

26. Spe infra note 43 and accompanying text. 
their objectives and concerns, the law may discover opportunities to bring about material increases in litigant satisfaction in exchange for a minimal commitment of time and resources. We return to this theme in the conclusion of the article.

\section{IV}

\section{Substantive Goals: The Assessment of What Litigants Want}

One question that is common to almost every evaluative study of procedure is the frequency with which a given category of litigants (plaintiffs, defendants, tenants, consumers, or others) prevails. ${ }^{27}$ Counting winners and losers appears to be a straightforward task until one considers that it is first necessary to determine what the parties wanted when they came to court. For example, it is impossible to characterize a $\$ 500$ judgment for a plaintiff as either a success or failure without knowing the plaintiff's goals and expectations in bringing the suit. One potential source of such information is the plaintiff's complaint. However, as Vidmar argues, comparing a plaintiff's demands to what he actually receives may not be meaningful, because "the plaintiff's demand for compensation does not necessarily capture the difference between the parties." 28 Other information pertinent to measuring success may include the plaintiff's opinion about the worth of the case; the amount actually in dispute, taking into account any concessions the defendant may be willing to make; and any hidden agenda the plaintiff may be pursuing.

Analysis of the case of Mottley $v$. Newell illustrates the elusiveness of litigant objectives. The plaintiff, William Mottley, claims to have "co-signed"'? an installment sales contract to enable the defendant, Shirley Newell, to buy some furniture. Newell has failed to make the payments, and Mottley has paid two monthly installments at the demand of the furniture store. Mottley now seeks to enforce Newell's alleged promise to be responsible for the payments.

In Text 2A, the plaintiff gives the first indication of his desired result. Interestingly, this colloquy takes place before the judge has sworn the witnesses and is thus not evidence. Nonetheless, there can be no doubt that Mottley's objective is clearly communicated, even if not, as seen here, clearly understood.

\section{Text $2 \mathrm{~A}^{30}$}

JUDGE:

MOTTLEY:

Is William M-O-T-T-L-E-Y here?

Yes.

Uudge calls . ietuell.]

27. See, e.g., McEwen \& Maiman, supra note 12, at 6.

28. Vidmar, supra note 10 , at 516 .

29. It is unclear whether he is in fact a co-signer. He did not put the contract into evidence, and the judge did not ask him about its contents. The defendant testified that the plaintiff was the only signer.

30. It should be noted that Mottley is not a native speaker of American Fnglish, a fact that will help to explain some of the more unusual features of his testimony. We do not believe, however, that there are any essential differences between this litigant and the large number of others whose cases we have studied. 
JUDGE: $\quad$ Before you start, sir, um, what are you seeking here this morning?

MOTTLEY: Um, possession of my furn-, of the furniture.

JUDGE:

MOTTLEY:

Possession of furniture?

Yeah.

After the swearing of the parties, the judge invites Mottley to tell his story. In Text 2B, Mottley gives a lengthy account of his arrangement with Newell and his efforts to collect the payments from her.

\section{Text 2B}

JUDGE:

MOTILEY:
JUDGE:

MOTTLEY:
Mottley versus Shirley Newell. If you will, sir, you may begin. Court's in session at this time.

Um, Shirley New-, Newell, I don't know her before. Her girlfriend is my friend. I went to school with her. She [Newell's friend] introduced me to her [Newell] as her friend. So she [Newell] asked me. one, if I could co-sign for her to get some furniture from Rhodes Company, which I agree. I told her, I said, "I don't want to do it then, I don't want to do it then. Later on it will be trouble, but if you trust yourself that you would make the payment, I will help you." [He describes meeting Neurell at Rhodes Furmiture.] I signed the lease for her to get a dinette set and I left. When I left, she and Nicole [Newell's friend] went behind me to room furniture and added more items to, to the furniture. We, I think that that amounted to $\$ 820$. So when I got the first bill, because it is co-signed in my name, so they, they mailed the bill to me. So when it got, when it, when I got the first bill, I was mad.

So I got mad. I went to her, I said, "Look, what you did is not good, that fraudery. I could take you to court. But anyway, since we are all friend, if you make your payment. it's O.K. with me. Just make sure you make your payment." She said, "I'll make my payment. I always make my payment." I said, "You saying that now, but when time come, it will be trouble."

So the first payment [bill] came, the first payment came to me. I took the stuff [bill] to her house. She didn't even want to open the door. I had to, she opened the door. I gave it to her. I said, "I only brought this payment stub which is $\$ 44$ a month. It, it'll give you seventeen days to pay." I gave it to her at the beginning part of the month. So she said, "I'll pay my bill," and I left. After the seventeenth, about two weeks later. I call her one night. I said, "Have you made a payment?" She said, "Yes, I made my payment."

So when I looked this, on the month end of the second, the, uh, second bill came. I saw on it $\$ 88$. ." I said, "But how come? She told me she made her payment." Then I went to her house. When I went to her house, she said, "I have made a pavment." I said, "To who?" She lie to me. She called somebody who does not even work at Rhodes Furniture - she said she made payment to a girl. |.Mottley goes on to describe a lengthy discussion among. Newell, Nicole. and himself, as a result of which . Veuell paid him S88.j

She gave you how much money?

She gave me $\$ 88$ for the first $\$ 88$ I have already paid.

Several aspects of Text $2 \mathrm{~B}$ are notable. First, it is striking that Mottley begins his testimony by responding to an accusation-that he knew Newell "before"-that no one has made in court. The implication is that Mottley views his courtroom testimony not as a discrete episode with a clear beginning 
and end, but as part of an ongoing conversation. He and Newell are the principals in this conversation, with Nicole, the judge, and others drifting in and out as bit players. The fact that Mottley picks up this conversation in midstream, by responding to an accusation made at another time and place, also suggests that he has more in mind than the legal remedies of collection and repossession. In particular, his fixation on his continuing dialogue with Newell suggests that the specific legal problem he brings to court is symbolic of the larger problems in their relationship.

Relatedly, note the extraordinarily personal and dramatic quality of his account of the transaction. He continually uses direct quotation, reporting not only his conversations with Newell but even his soliloquizing on passing events ["I said, 'But how come?'"']. He sometimes steps out of his performing role to make evaluative comments about the characters in the drama ["I was mad"; "she lie to me"]. The effect of all this is to underline his emotional stake in what purports to be a business transaction with a person whom he did not know "before."

The judge's single interruption in this lengthy narrative indicates that his focus is on the narrow issues of specific legal relevance rather than on the unfolding personal drama. The interruption is particularly interesting because it seems gratuitious: Can the judge possibly have missed the twicestated point, "She gave me $\$ 88$ "? One is tempted to interpret the judge's interruption not as a question, but as an emphatic statement about the limits of the court's interest and power.

After Text 2B, Mottley continues his narrative in the same fashion, replete with performance and personal commentary. He repeats his description of collecting the initial $\$ 88$ payment, and then recounts his receipt of the bill for the third month. Once again, the judge interrupts, ostensibly to clarify issues of legal relevance.

\section{Text 2C}

MOTTLEY:

JUDGE:

MOTTLEY: JUDGE:

MOTTLEY:

JUDGE:

MOTTLEY:

JUDGE:

MOTTLEY:

JUDGE:

MOTTLEY:

JUDGE:

MOTTLEY:

JUDGE:

MOTTLEY:

JUDGE:

MOTTI.EY:
Last month, the stuff came. When I -, the stuff came. When I took the stuff to her house, she won't open the door.

Let me ask you a question, sir. Where is the furniture at this lime?

She, she, she had it to her house.

Now, inasmuch as you are saying that, um, Ms. Newell has this furniture that you co-signed for...

Yeah.

Now, how about the deal with, uh, Rhodes Furniture Company? Who is taking care of that?

I am taking care of it now.

So, you are paying this bill?

On my own now.

On your own, to Rhodes Furniture Company?

Yeah, yeah-because it's in my name.

Yeah, I understand.

And I don't want my credit to spoil.

I understand, you co-signed for Ms. Newell.

That's right.

Thank you very much.

I'm not through. 
After thus seizing the floor at the end of the judge's interrogation, Mottley recycles his narrative, returning to his description of Newell's refusal to open the door. He tells of filing the suit for the third and fourth months' payments, and his difficulties in obtaining service. Then, in Text 2D, he concludes his presentation by reiterating his opening demand for repossession.

TExT 2D

MOTTLEY: $\quad$ I went back and make another payment again before I file to her working place. There where they-I think that where they got her-that why she been, she been hiding. And then two month and she had not pay, so I, I had paid it two months. I want to repossess the furniture. I will take over the, if I don't need it, I need it, but I, I will take, I will take care of it.

The judge turns to Newell for her version in Text 2E. She responds directly to several of Mottley's accusations, and offers explanations for her behavior, but does not address the basic question of the debt.

\section{TExT 2E}

JUDGE: Um, Ms. Newell, you have heard the testimony coming from the gentleman here. If you have something, the court will honor it at this time.

NEWELL: Yes, I do. First of all, Mr. Mottley knew exactly what I was getting, because Jack Roy, the salesman at the store, told him, showed him the paper in which what was written on there, that I was getting. They said there was no way that anyone could go and add anything on his account, because it's in his name-he did not co-sign. It's in his name, period. Mr. Mottley came to my house before the seventeenth. The bill is past due on the seventeenth of the month. I told him at that time I had gave my money to my friend to go pay for me because I had no transportation. . [she explains why she has no receipt for the payment].

As far as him saving that I was dodging the sheriff, Mr. Mottley and your honor, I have not been in my home since June 10th, due to the simple fact that I had no lights. I was with my mother. On June 2 lst, we went to Lancaster. South Carolina, for a funeral.

At this point the judge intervenes and begins to move the parties toward a settlement. Before ultimately succeeding, he encounters resistance from each of them. Newell continues to avoid his direct questions about the debt, insisting instead on repeating her denials of Mottley's allegations about her behavior. For his part, Mottley continues to press for repossession, but never elicits a direct response from the judge.

\section{TExt 2F}

$\begin{array}{ll}\text { JUDGE: } & \text { Sir, how much money, uh, does Ms. Newell owe you at this } \\ & \text { particular time? } \\ \text { MOTIELY: } & \text { Um, at this particular time, she owe two month rent. She } \ldots \\ \text { JUDGE: } & \text { And the payments are how much a month? } \\ \text { MOTTLEY: } & \$ 44 \text { a month. } \\ \text { JUDGE: } & \$ 44 \text { a month? } \\ \text { MOTlLEY: } & \text { Yes. } \\ \text { JUDGE: } & \text { And she's two payments behind at this time? } \\ \text { MOTILEY: } & \text { Yeah, yeah. }\end{array}$


JUDGE:

NEWELL:

JUDGE:

NEWELL:

MOTTLEY:

NEWELL:

MOTTLEY:

JUDGE:

MOTTLEY AND

NEWELL:

JUDGE:

NEWELL:

JUDGE:

NEWELL:

JUDGE:

NEWELL:

JUDGE:

MOTTLEY:

JUDGE:

MOTTLEY:

JUDGE:

MOTTLEY:

JUDGE:

MOTTLEY:

JUDGE:

NEWELL:

JUDGE:

NEWELL:

JUDGE:

NEWELL:

JUDGE:
Ms. Newell, do you have any intention of paying this money, uh, to this gentleman here in relationship to him having paid it already?

As I said, your honor, I have been out of town. My greatgrandmother has passed away.

Well now, I can understand that, but I'm asking you ....

When I returned to my home on the first, the office manager and the neighbor told me that Mr. Newell was at my door. They had to fix my door in which I have to pay for, because he kicked it.

No, I didn't.

Yes, he did.

[Laughing].

Now let me ask you a question, um, Ms. Newell -

[Both laughing].

Did you intend to pay this amount of money that's owed on this furniture at this time?

I had every intentions to pay. When I returned, I called my job. They told me that the sheriff had been there. I called downtown in which I talked with the sheriff of car 619. He cold me that he had a paper for me and I told him exactly where I was. I gave him the phone number. I had no reason to hide.

Ms. Newell, when do you plan to pay this money that, uh, was owed to this gentleman here?

He can have it tomorrow if he wants, but, if he wants his furniture, he's . . .

I'm asking a question: When do you plan to pay him the money that's owed at this time?

I had planned to pay him when I returned from out of town.

Then Mr., uh, sir, would you be willing to accept the payments that are due at this particular point from Ms. Newell?

Um, sir, to, to, to ease her problem, I would, I would, I wouldn't regret past payment. I would just like to possess the furniture. Then, I don't have to be bothered with nobody at this point of time. She owe me two months' money, it's O.K., I will, I need it.

The question that I'm asking you, inasmuch as, um, Ms. Newell does owe you this money...

Uh-huh.

... are you willing to accept this money that she owes you, uh, to Rhodes on this bill?

Yeah.

You are willing to do that?

Yeah.

Ms. Newell, when do you plan to pay this money to, uh, this gentleman here?

That's what I'm trying to explain. As I said, I was willing to pay him when I left. And when I returned, and then when I came back to a job, which I was fired from, because of the sheriff.

Well, when do you plan to, when do you plan to pay the gentleman?

I can pay him next week.

What day next week can you pay him?

What's the date, the 13th? Round the 24th.

After listening to the testimony from the plaintiff and the defendant, in relationship, sir, to what was said by Ms. Newell here that she was gonna pay you this amount of money that's owed in order to bring this account up to date on the 24th of 
this month, I'm gonna continue this case until the 27th, June 27 th, 86 at 11 a.m. Now, if this, uh, money has been paid to you in that period of time. .

MOTTLEY:

JUDGE:

Uh-hum.

... of course, you can call me at my office and I'll be able to handle the situation at that point. Now, if this is not done on the $24 \mathrm{th}$, I'm gonna hear the case on the $27 \mathrm{th}$ of June ' 86 at $1 \mathrm{I}$ a.m., and I'm gonna enter a judgment at that time.

By almost any objective measure, this outcome would be deemed a success-for the plaintiff, the system, and even the defendant. The plaintiff has the defendant's agreement to pay the arrearage, backed up by the threat of a judgment. The judge has ignored Mottley's claim for repossession, but there is no clear evidence that he is entitled to that remedy. ${ }^{31}$ Mottley appears to have secured a legal victory, along with some practical help in collecting his prospective judgment. The result also seems ideal from the perspective of the judicial system. Rather than simply pronouncing judgment, the judge has used his authority as leverage in moving the parties toward a consensual resolution, with an attendant increase in the likelihood of compliance. ${ }^{32}$ Presumably, a plaintiff who both wins and gets paid will be a satisfied customer of the system. The outcome is positive even for Newell, given the fact that she never denies the agreement with Mottley or her failure to pay. She keeps the furniture, she has two more weeks to pay, and, if she does so, she avoids the entry of a judgment against her. Moreover, she has had an opportunity to defend her conduct and denounce Mottley's, an opportunity that seems to have been important to her.

There is evidence, however, that the judge's decision entirely misses the point of the dispute, and is thus likely to be a source of more trouble rather than a source of satisfaction. Recall, for example, that Mottley began the case by denying a legally irrelevant accusation about his relationship with Newell that she must have made at another time and place. For her part, Newell ignored the legal thrust of his case, even when the judge demanded that she address it, and insisted on justifying her conduct during the relationship. Note also Mottley's repeated demands for repossession, and in particular his comment that "I would just like to possess the furniture. Then, I don't have to be bothered with nobody...."

In separate interviews immediately after the trial, Mottley and Newell elaborated on these hints and shed further light on their hidden agendas and their satisfaction with the outcome. In Text 2G, Mottley responds to a question about whether he was satisfied with the trial. He focuses more directly on his interest in repossession as a way to end his dealings with Newell, and asks the interviewer, almost plaintively, if she appreciates the point that the judge apparently missed.

31. The documentation for the Rhodes Furniture transaction was not put into evidence. Mottley's testimony suggests only an oral agreement that he would guarantee Newell's debt in exchange for her promise to make the payments.

32. See McEwen \& Maiman, . Mediation in Small Claims Court: Achieving Complianre Through Consemt. 18 I AW \& SOC'Y REV. 11 ( 1984$).$ 
Text 2G

MOTTLEY: Well, with the judge running this, he spoke about, it would be too much for me. You know, my main point is, if I could possess my furniture.

INTERVIEWER: Is that what you really wanted to do?

MOTTLEY: Yeah, I would be, I would, I don't have to be bothered with her, I would be O.K. You see?

INTERVIEWER: Uh-huh.

MOTTLEY: $\quad$ You see, that's all I want. [Mottley departs hurriedly.]

Finally, in an interview a few minutes later, Newell solves the mystery of the hidden agenda. Text $2 \mathrm{H}$ begins in the middle of Newell's retelling the story of Mottley coming to her home to collect the payments.

\section{TExT 2H}

NEWELI:

There was a lot, the day he said he came by and I wouldn't let him in, the man wanted me to open the door naked. I was getting out of the shower, and he expected me to jump up and run down to the door. But he got in. And he was nasty. And the reason I refused to argue with him [in court], "cause he was lying. And I knew that judge knew he was lying. And the fact about he didn't know what was on that stuff [the Rhodes documents], he [Motley| knew. And I started to tell the judge the exact truth as to why he decided to come to court...

INTERVIEWER: Why is that?

NEWELL: .. . but I felt that it was like personal.

INTERVIEWER: Right.

NEWELLL:

I turned him down.

INTERVIEWER:

Oh yeah?

NEWELI:

And that stuff was bought as a gift, all right.

INTERVIEWER:

When you first, like, bought the stuff, did you think you'd have to pay him at all?

NEWELL:

Uh-uh [negative]. But then I told him that my intentions was wrong as far as except, um, letting him give, and I would prefer to pay him, because he was expecting a little more, and I wasn't going to give him no more [laughter].

[Newell comments further on Mouley's aggressize behavior, and explains that her friend introduced . Mottley to her "lo get him off her back."]

INTERVIEWER: Did you want the furniture to begin with, or is it just something that he got you? I mean, now that you've got it, do you want to go ahead and pay for it, or...

NEWELL: The truth?

INTERVIEWER: Yeah.

NEWELL: I was hoping he'd tell that man he could have his stuff. I really was. Because he's a pest. He is a home pest.

Newell's revelation finally explains the enigma of the parties' trial tactics. ${ }^{33}$ Mottley's repeated demands for repossession now seem less a property claim than a request for what amounts to a divorce, a divorce to which Newell would consent. Those aspects of their testimony that seemed so out of place in a contract case-for example, his response to a pre-existing accusation about the start of their relationship, and her insistence on constantly justifying her

33. It may be significant that the interviewer is a female law student of about the same age as Newell. 
conduct-are perfectly appropriate in the context of a domestic relations case. Indeed, such issues are the essence of a domestic case.

From this perspective, the result reached by the judge looks far less successful. Its substantive terms are unresponsive to the real desires of the parties. From a procedural standpoint, the judge's mediating approach seems to be exactly what the parties do not want or need. They are tired of dealing with each other and have looked to the court for a termination of their relationship that they seem unable to bring about by themselves. Instead, the court extends the relationship for at least two more weeks.

We do not mean to suggest that in this case the judge could or should have addressed the subjective needs of the parties. In limiting himself to the two payments currently in arrears, the judge avoided a number of difficult, perhaps irreconcilable, legal and factual issues pertaining to the effect of the missing contract documents and the terms of the oral contract between Mottley and Newell. Moreover, his tactic of maneuvering the parties into an agreement is in accord with the prevailing view that mediation promotes compliance. ${ }^{34}$ Since his court has authority only to issue money judgments, one can hardly criticize him for not engaging in what Vidmar calls "deep" mediation, which involves "exploration of non-legal issues that might underlie the dispute."'35

Our point, rather, concerns the difficulty of classifying an outcome as "successful" for a particular litigant or for the system. In this case, the docket showed only a claim for an unpaid debt, an agreement by the defendant to pay, and a dismissal before any judgment was entered. Attendance at the trial and study of the trial transcript seemed only to confirm the appearance of success all around: The plaintiff got much of what he asked for, the defendant avoided the onus of a judgment, and the judge brought it all about by leading the parties toward a settlement. The hidden agenda of the parties, and the value of the outcome in relation to it, become clear only when a persistentand, fortuitously, young, female-posttrial interviewer strikes a responsive chord and elicits "the exact truth" from Newell.

\section{V \\ Conclusion}

Cases such as these present a strong argument for the value of detailed qualitative research in the evaluation of procedural reform. In order to determine whether a given reform meets a particular need, it is first necessary to define that need with precision. The goal of informal justice, as practiced in small claims courts, has often been defined in terms of meeting the needs of ordinary people with real economic grievances who cannot afford real litigation. ${ }^{3 i}$ Research assessing the success of informal justice has, in turn,

34. Sep McEwen \& Maiman, supra nole 32

35. See Vidmar, supra note 10 , at 523.

36. Sep J. Ruhnka \& S. Weli.er, Small Clalms Colikts: A National. Examination l-5 (1978). 
tended to assume that litigants are primarily motivated by rational economic concerns. ${ }^{37}$ Efforts at greater precision in measuring success have focused primarily on refining the analysis of the system's ability to meet litigants' presumed economic concerns. As for non-economic motives, analysts have tended either to ignore them or to note them but then put them aside as too difficult to quantify or control. ${ }^{38}$

In examining litigants' statements in presenting their cases as well as their statements before and after the presentation, we are constantly reminded of the importance-if not the preeminence-of non-economic factors. In large numbers of cases, there is compelling linguistic evidence that a hidden agenda is the primary agenda. Repeatedly, parties press ahead in objectively hopeless cases, apparently driven by a need to prove something to themselves, to have a person in authority affirm the importance of their problems, or to achieve some social objective only indirectly related to the litigation."39 Conversely, many litigants such as Freeman and Mottley "win" their cases but still come away dissatisfied with the process because it has failed in some significant way to meet these other needs.

The point of this argument is not that the legal system should adopt the goal of identifying and satisfying litigants' personal and social needs. Rather, in evaluating the existing litigation process and designing alternatives to it, the law should not leave unexamined the assumptions about rational economic goals that permeate the civil justice system. For example, if one were designing a pretrial mediation program, the objective presumably would be to settle cases by moving litigants to a position of mutual satisfaction. The assumption that litigants are primarily motivated by a desire to maximize their economic return might lead to a design wherein lawyers exchange demands and offers, with comments by the mediator on likelihood of success at trial. However, these data suggest that mutual satisfaction is frequently more than a matter of financial accord. Thus, a design that took into account the concerns that litigants express might put considerable emphasis on such a simple expedient as giving the litigants an unfettered opportunity to state their case to someone in a position of authority. ${ }^{40}$

This discussion raises the obvious question of the applicability of our findings to formal justice. The phenomena described in this article are widespread among informal court litigants. Are these concerns also significant to litigants in larger cases in "real" courts, particularly litigants

37. There are a number of studies of informal justice that examine litigant behavior in detail. Even in these studies, however, it is usually assumed that the issue is a "dispute" that is within the competence of the forum. See. e.g. Mather \& Yngvesson, Language, Audience and the Transformation of Dispules, 15 LAW \& Soc'Y Rrv. 775 (1980-81). Cf. McEwen \& Maiman, supra note 32 (investigating structural and psychological factors that promote differential compliance with judgments in mediation and adjudication)

38. See, e.g., Vidmar, supra note 10 , at 521 .

39. As one litigant testified, "The reason I'm fighting so hard is that if I don't get something back at home my wife was gonna, you know, really take care of me."

40. Cf. Felstiner, Abel \& Sarat, The Transformation of Dispules: Naming. Blaming. Claiming . ... 15 IAW \& Soc'Y REv. 631, 648-49 (1980-81) (comparing law and psychotherapy). 
acting on behalf of corporations? At this point in our research we do not know. Anecdotal evidence from lawyers and clients ${ }^{41}$ and personal experience ${ }^{42}$ suggests, however, that non-economic hidden agendas may be far more important in commercial litigation than has generally been assumed. We view this as an interesting and important question for further research. ${ }^{+3}$ In conclusion, we argue that all facets of a litigant's motivation need to be discovered and factored into the process of procedural reform. We suggest that detailed, qualitative analysis of unrehearsed litigant speech is an effective means of uncovering the full range of litigant concerns, and that such analysis should be an essential component of the empirical study of legal procedure. Both empiricists and theoreticians must avoid becoming so absorbed in the demands of their own traditions of thought that they forget the value of listening to what people are telling them.

41. We have raised this question frequently with lawyers and formal court litigants in the course of 15 years of empirical study of the legal system.

42. One of us (Conley) has been a teacher and practitioner of civil litigation for 12 years.

43. Our findings may also have implications for legal education. As the presence of interviewing, negotiation, and client counseling courses attests, the curriculum in most law schools is giving increasing attention to the need to understand and communicate effectively with clicnts. We believe that the study of litigant speech can make an important contribution to the development of a coherent theoretical base for this eflort. 
